\title{
Model Pengasuhan Anak Usia 3-4 Tahun Berbasis Practical Life di Homeschooling Tunggal
}

\author{
Widia Winata ${ }^{1}$, Ahmad Susanto ${ }^{2}$, Ahmad Suryadi ${ }^{3}$, Malpaleni Satriana ${ }^{4}$, Siti Rohaeni ${ }^{5}$ \\ Teknologi Pendidikan, Universitas Muhammadiyah Jakarta, Indonesia(1), Pendidikan Guru \\ Sekolah Dasar, Universitas Muhammadiyah Jakarta, Indonesia(2), Teknologi Pendidikan, \\ Universitas Muhammadiyah Jakarta, Indonesia(3), Pendidikan Guru Pendidikan Anak Usia \\ Dini, Universitas Mulawarman Samarinda, Indonesia(4), KB/TK Labschool Fakultas Ilmu \\ Pendidikan, Universitas Muhammadiyah Jakarta, Indonesia(5) \\ DOI: $\underline{10.31004 / o b s e s i . v 6 i 2.1492}$
}

\begin{abstract}
Abstrak
Anak usia dini berada dalam fase bermain, bergerak secara aktif. Munculnya penggunaan teknologi membuat anak cenderung banyak menggunakan media tersebut dan membuat anak kurang bergerak. Oleh karenanya dibutuhkan model pengasuhan di era digital yang berbasis practical life agar aktivitas anak dapat seimbang. Tujuan penelitian ini untuk menemukan model pengasuhan berbasis practical life sebagai upaya preventif menghindari pengaruh negatif penggunaan teknologi. Model dikembangkan berdasarkan teori Montessori yang dipadukan dengan Research and Development model Dick and Carey. Desain pembelajaran disusun untuk anak usia 3-4 tahun yang diasuh di rumah (homeschooling tunggal). Penelitian ini berlangsung selama satu tahun dengan teknik pengumpulan data; observasi, wawancara, dan dokumentasi. Data dianalisis secara kualitatif dan kuantitatif sederhana dengan mengikuti langkah model Dick and Carey; mengidentifikasi pembelajaran, melaksanakan, dan mengevaluasi pembelajaran. Hasil penelitian menampilkan langkah model pengasuhan dimulai dari need assessment, demonstrasi, latihan independen, relasi konteks lain, dan evaluasi sebagai langkah preventif dalam menanggulangi pengaruh negatif penggunaan teknologi.
\end{abstract}

Kata Kunci: model pengasuhan; anak usia 3-4 tahun; practical life; aspek perkembangan anak; homeschooling.

\begin{abstract}
Early childhood is in the play phase, moving actively. The emergence of the use of technology makes children tend to use the media a lot and make children less mobile. Therefore we need a parenting model in the digital era that is based on practical life so that children's activities can be balanced. The purpose of this study is to find a practical life-based parenting model as a preventive effort to avoid the negative effects of using technology. The model was developed based on the Montessori theory combined with the Dick and Carey Research and Development model. The learning design is prepared for children aged 3-4 years who are cared for at home (single homeschooling). This research lasted for one year with data collection techniques; observation, interview, and documentation. Data were analyzed qualitatively and quantitatively simply by following the steps of the Dick and Carey model; identify learning, implement, and evaluate learning. The results of the study show the steps of the parenting model starting from need assessment, demonstration, independent exercise, other contextual relationships, and evaluation as a preventive measure in overcoming the negative effects of using technology.
\end{abstract}

Keywords: parenting model; children aged 3-4 years; practical life; aspects of child development; homeschooling.

Copyright (c) 2021 Widia Winata, Ahmad Susanto, Ahmad Suryadi, Malpaleni Satriana, Siti Rohaeni

$\square$ Corresponding author:

Email Address : widia.winata@umj.ac.id (Bogor, Jawa Barat, Indonesia)

Received 4 January 2021, Accepted 19 June 2021, Published 26 June 2021

680 | Jurnal Obsesi: Jurnal Pendidikan Anak Usia Dini, 6(2), 2022 


\section{PENDAHULUAN}

Perkembangan dunia saat ini sudah memasuki revolusi industri 4.0 dan era society 5.0 yang ditandai dengan penggunaan teknologi di berbagai aspek kehidupan (Efendi, 2018). Kecanggihan teknologi bukan saja memiliki pengaruh positif namun aspek negatifnya juga harus diperhatikan. Apalagi hal ini merambah pada anak-anak usia dini yang sudah familiar dengan penggunaan media teknologi seperti game online, youtube, tik tok, dan media sosial lainnya (Santoso, 2017). Penggunaan teknologi memang sudah diatur dalam peraturan pemerintah namun tidak menutup kemungkinan hal ini tidak sampai pada penggunaan di level anak-anak (Nurhidayati et al., 2021).

Anak-anak selayaknya dilindungi bukan saja dari aspek kekerasan fisik namun juga pengaruh negatif penggunaan teknologi informasi (Risma et al., 2019). Pemerintah sudah mengamanahkan bahwa pendidikan anak usia dini diarahkan pada upaya pembinaan yang ditujukan kepada anak sejak usia lahir sampai usia 6 tahun yang dilakukan melalui pemberian rancangan pendidikan untuk membantu pertumbuhan dan perkembangan jasmani dan rohani agar anak memiliki kesiapan dalam memasuki pendidikan lebih lanjut. Pengertian ini disampaikan kembali oleh Anhusadar dan Islamiyah dalam hasil risetnya (Anhusadar \& Islamiyah, 2020). Penekanan pemberian rancangan pendidikan juga dimaksudkan agar anak terlindungi dari pengaruh negatif penggunaan teknologi saat ini. Salah satu upaya yang dilakukan adalah merancang model-model pendidikan atau pengasuhan yang dapat memberikan keseimbangan dalam pertumbuhan dan perkembangan anak.

Penggunaan media teknologi pada anak yang melebihi dari delapan jam dalam sehari menuai masalah. Bukan saja aspek perkembangan motoriknya yang terganggu, namun kognitif dan sosial emosionalnya juga dapat terganggu (Munisa, 2020), (Utami \& Mubarak, 2018). Anak yang sudah kecanduan akan menarik diri dari pergaulan dan sulit diajak berkomunikasi. Penggunaan teknologi secara berlebihan ini dikatakan Lumanta telah terbukti memberikan pengaruh buruk bagi perkembangan anak (Lumanta et al., 2019). Untuk mengatasi hal tersebut Lumanta memberikan solusi dari aspek teknologi informasi juga yakni dengan menggunakan UI (User Interface) dan UX (User Experience). Alat tersebut dapat memberikan informasi kepada orang tua sejauh mana kecanduan yang dialami anak dan memberikan solusi bagaimana cara mengatasi hal tersebut (Lumanta et al., 2019).

Jika dilihat dari apa yang dilakukan Lumanta, penanganan yang dilakukan setelah terjadi kecanduan bukan pada pencegahan. Orang tua memiliki alat untuk mendeteksi agar kecanduan anak dapat dikategorikan pada level berapa dan metode penanganannya. Di luar penelitian ini, terdapat tindakan preventif yang dilakukan orang tua sebelum anak terpapar kecanduan. Seperti yang dilakukan oleh Nuraina dan kawan-kawan, menurutnya penggunaan teknologi jika tidak didampingi oleh orang dewasa bisa berdampak negatif dan mengalami kecanduan. Tim riset ini memberikan solusi aktivitas menarik yang dapat dilakukan anak bersama orang tua untuk mengantisipasi pengaruh negatif penggunaan teknologi (Nuraina et al., 2018). Budaya leluhur ini perlu dilestarikan supaya anak-anak tetap dapat membangun imajinasinya dan mengembangkan potensi yang dimilikinya.

Apa yang dilakukan penelitian sebelumnya ini menginspirasi riset bahwa ada upaya lain yang bisa dilakukan sebagai pencegahan atau preventif. Namun belum ada rancangan model pembelajaran yang dibuat sebagai pencegahan seperti model pengasuhan berbasis practical life. Meskipun model ini merujuk pada konsep dasar Montessori namun keberadaannya disesuaikan dengan kebutuhan anak Indonesia khususnya anak di homeschooling tunggal. Dimana peran keluarga menjadi sangat penting dalam mendampingi tumbuh kembang anak-anak di rumah.

Dari kajian literatur yang relevan didapatkan bahwa practical life digunakan oleh guru dalam proses pembelajaran di kelas untuk meningkatkan kemandirian anak (Rantina, 2015), (Fitri, 2018), (Kurniawati \& Hayati, 2020). Beberapa penelitian lainnya mengarah pada pengembangan motorik anak agar anak-anak dapat mengembangkan gerak motorik halus dan kasarnya dengan melakukan aktivitas-aktivitas practical life (Rule \& Stewart, 2002), (Bhatia 
et al., 2015). Hal ini sangat logis mengingat practical life merupakan aktivitas fisik yang mengacu pada realitas kehidupan sehari-hari. Dalam melakukan hal tersebut kedua apsek kemandirian dan fisik motorik dapat dikembangkan. Namun bagaimana dengan pengembangan aspek menyeluruh secara integratif dalam setting rumah untuk anak usia 3-4 tahun? Inilah yang belum ditelaah.

Berdasarkan kajian tersebut perlu dilakukan penelitian yang terkait practical life dalam pengasuhan. Hal ini dapat dikatakan sebagai state of the art dalam bentuk penemuan model pengasuhan anak usia 3-4 tahun berbasis practical life dalam rangka pengembangan 6 aspek perkembangan anak; nilai agama dan moral, fisik motorik, kognitif, bahasa, sosial emosional, dan seni kreativitas. Practical life juga diharapkan menjadi langkah preventif dalam menanggulangi pengaruh negatif penggunaan teknologi. Tujuan ini diikutsertakan supaya orang tua di rumah memiliki alternatif kegiatan practical life yang mengusung aktivitas seimbang dalam mendampingi anak-anaknya bermain dan belajar di rumah di era kecanggihan teknologi.

Model pengasuhan anak adalah intervensi perkembangan yang dilakukan orang tua kepada anaknya yang berusia dini. Pengasuhan merupakan salah satu pendekatan yang digunakan untuk mendorong perkembangan anak, baik perkembangan secara umum maupun sosial emosionalnya yang dilakukan oleh orang tua di rumah (Nurendah et al., 2019). Ini berlaku baik untuk anak yang berkembang secara normal maupun anak berkebutuhan khusus. Salah satu bentuk model pengasuhan adalah menyisipkan teori practical life karya Montessori. Pelaksanaan pengasuhan kepada anak harus memuat tiga unsur yakni lingkungan, pengasuh dan anak. Ketiga hal ini saling berhubungan satu dengan yang lainnya. Pengasuh memiliki peran yang sangat penting dalam menyiapkan lingkungan belajar anak secara bebas (Lillard, 2013).

Practical life dimaknai sebagai latihan kehidupan nyata yang menghubungkan seseorang dengan lingkungan sosialnya. Praktek kehidupan nyata ini disebut juga dengan keterampilan hidup; hal-hal yang real dilakukan dalam kehidupan manusia sehari-hari Langkah yang dilakukan dalam model pengasuhan practical life adalah mempresentasikan cara latihan kepada anak, anak melakukan latihan secara independen, anak menggunakan pengetahuannya tentang aktivitas pada konteks lain (Stendler, 1965). Pada usia 3-4 tahun anak usia dini sudah mampu melakukan aktivitas practical life karena otot-ototnya sudah berkembang dengan baik seperti layaknya orang dewasa.

Aktivitas-aktivitas practical life seperti mencuci baju, mengepel lantai, mengelap meja, memeras jeruk, menjemur pakaian, mencuci piring, menyapu, menyusun barang, mengangkat barang, bercerita pengalaman, membuka pintu, mengunci pintu, mengaduk minuman, memotong cabe, menuangkan air ke dalam mangkuk, memindahkan biji-bijian, mandi, menggosok gigi, memangkas rumput, menyimpan mainan ke tempatnya, memasak sederhana, membuat es cream, melipat baju, menulis permulaan, membaca permulaan dan berhitung permulaan. Intinya semua aktivitas real yang dilakukan sehari-hari itulah yang disebut dengan practical life. Jadi anak tidak diarahkan bermain atau berkegiatan dengan benda tiruan tetapi langsung pada kegiatan nyata. Meskipun dalam kenyataannya ada sebagian ketertarikan anak pada benda tiruan seperti boneka atau mainan plastik, namun porsinya amatlah sedikit jika dibandingkan dengan benda dan aktivitas practical life.

Jika dilihat dari sisi perkembangan, anak usia 3-4 tahun disebut sebagai toddler (Marshall, 2017). Toddler mengacu pada istilah anak di bawah usia lima tahun atau batas akhir usia enam tahun saat anak-anak akan memasuki usia Sekolah Dasar (SD). Pada usia ini anakanak sudah mampu mengucapkan banyak kata dan kalimat sehingga mampu untuk memahami bahasa sesuai dengan relevansinya, memahami pembicaraan orang lain, dan menjawab pertanyaan yang diajukan kepadanya. Bahkan di usia 3 tahun anak-anak sudah bisa menjalankan perintah yang diberikan kepadanya, misalnya: "bisakah kamu menuangkan garam ke dalam mangkuk ini?"(Bhatia et al., 2015). Bahkan anak sudah mampu melaksanakan dua perintah sekaligus seperti "tolong ambilkan gelas dan isi air di dalamnya". 
Pada usia 3-4 tahun anak-anak sudah memahami gender, dia perempuan atau lakilaki. Referensi ini digunakan dalam hubungan sosialnya terutama dalam pertemanan. Mereka sudah mulai membentuk komunikasi dengan dunia luar dan kontak sosial yang lebih luas (Wulandari \& Purwanta, 2020). Pertanyaan-pertanyaan seputar gender juga bermunculan seperti "aku cewek ya ma, dia cowok?" ketika anak perempuan melihat teman lelakinya berjalan di depannya. Di samping pemahaman gender, anak usia 3-4 tahun sudah memahami konsep bilangan sederhana, membandingkan jumlah, menemukan pola, ruang, menyelesaikan permasalahan seperti membangun balok-balok agar tidak jatuh dan berbagi makanan dengan teman sebaya (Tampubolon et al., 2019).

\section{METODOLOGI}

Metode penelitian ini menggunakan Research and Development model Dick and Carey dengan langkah mengidentifikasi tujuan pembelajaran, melakukan analisis pembelajaran, menganalisis anak dan konteksnya, menulis tujuan kinerja, mengembangkan instrumen penilaian, mengembangkan strategi pembelajaran, mengembangkan dan memilih bahan ajar, merancang dan melakukan evaluasi formatif pembelajaran, merevisi pembelajaran, merancang dan melakukan evaluasi sumatif (Creswel, 2009). Metode ini dipilih karena sistematika risetnya yang sesuai dengan kebutuhan yakni pengembangan model pengasuhan dengan mengedepankan langkah yang terstruktur dan sistematis. Alasan lainnya adalah konteks anak usia dini yang sederhana bisa disadur dari langkah Dick and Carey yang ada sehingga peneliti tidak mendesain dari awal atau dasar. Setelah dimodifikasi dengan teori Montessori maka desain pengasuhan menjadi seperti ini:

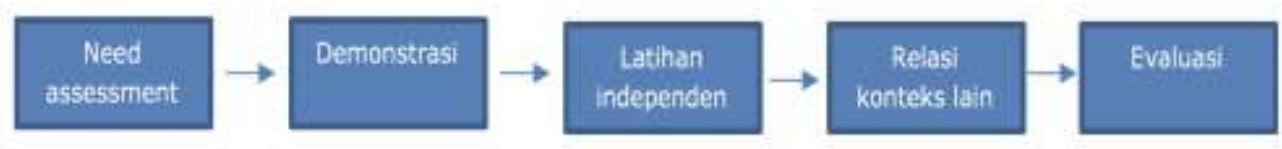

Gambar 1. Model Pengasuhan Anak Usia 3-4 Tahun Berbasis Practical Life

Need assessment yang dilihat dari tahap perkembangan anak saat diterapkan model ini. Berdasarkan tahap perkembangan tersebut disusun tujuan pembelajaran yang disesuaikan dengan kemampuan yang harus dimiliki anak dalam Standar Tingkat Pencapaian Perkembangan Anak (STPPA). Hal ini dilakukan agar tujuan pembelajaran tetap mengacu pada standar yang sudah ditetapkan pemerintah. Setelah mengetahui tahap perkembangan anak, maka disusun tujuan pembelajaran atau pengasuhan sehari-hari.

Demonstrasi merupakan role model yang dilakukan orang tua dalam kehidupan seharihari. Pelaksanaan practical life atau kehidupan praktis orang tua akan ditiru anak, oleh karenanya orang tua harus memberikan tauladan yang baik agar dapat disadur oleh anak dengan baik pula. Latihan independen dilakukan anak secara mandiri dengan mangacu pada role model orang tua, bahkan kreativitas anak dimungkinkan terjadi pada tahap ini melampaui pengetahuan orang tuanya. Relasi konteks lain merupakan hubungan kegiatan yang sedang berlangsung dengan kegiatan lainnya yang saling berhubungan. Evaluasi dilakukan untuk melihat ketercapaian target yang diinginkan agar terlihat bagaimana progress perkembangan anak dari 6 aspek perkembangan anak.

Teknik penentuan sampel dilakukan secara accidental sampling dengan seorang anak perempuan berusia 3-4 tahun yang diasuh di rumah oleh keluarga; ayah, ibu, dan kakak. Kakak yang berusia 15 tahun juga dididik secara homeschooling tunggal di rumah. Keputusan untuk memilih unschool dikarenakan alasan di antaranya, anak tidak berminat mengikuti sekolah formal, figur guru di sekolah yang tidak menarik, proses belajar yang bersifat textbook, bakat dan minat anak tidak sesuai dengan kurikulum di sekolah, dan adanya perilaku bullying di sekolah. Keikutsertaan pakar seperti narasumber lain yang dibutuhkan turut menjadi pengaya dalam proses belajar anak di homeschooling. Dalam penelitian ini, setting homeschooling yang dipilih adalah homeschooling tunggal dengan latar belakang keluarga, mengingat anak 
usia dini lebih banyak menghabiskan waktu bersama keluarga. Kegiatan penunjang hanya dilakukan sekali dalam seminggu seperti menari balet dan musik untuk menambah skill anak yang tidak mampu dilakukan oleh orang tua di rumah.

Teknik pengumpulan data yang digunakan adalah observasi, wawancara, dokumentasi, dan teknik penilaian yang bersifat kuantitatif sederhana. Analisa data dilakukan secara kualitatif dan kuantitatif sederhana pada tiap langkah yang ditempuh. Proses analisis data kualitatif dimulai dari pengumpulan data yang berasal dari hasil observasi, wawancara dan dokumentasi. Data lalu disortir, diklasifikasikan, diberi kode, diinterpretasikan, dan dielaborasi. Validasi data dilakukan dengan teknik perpanjangan keikutsertaan, klarifikasi kasus (case clarification), demonstrasi parallel (parallel demonstration) dan mencocokkan pola (pattern matching). Sementara analisis data kuantitatif sederhana berlaku pada instrumen penilaian hasil belajar anak yang diukur secara sederhana.

\section{HASIL DAN PEMBAHASAN}

Hasil penelitian menunjukkan bahwa model pengasuhan berbasis practical life dapat diterapkan kepada anak usia 3-4 tahun untuk mengembangkan 6 aspek perkembangan anak; nilai agama dan moral, fisik motorik, kognitif, bahasa, sosial emosional, dan seni kreativitas. Hal tersebut dilakukan sebagai dasar dalam melanjutkan pendidikan berikut di Taman Kanak-kanak (TK) dan SD. Hal ini dapat dilihat dalam perkembangan anak yang terus meningkat. Menurut hasil penelitian yang dilakukan oleh Jensen, Shute dan Wallis dalam Schunk, menjelang usia lima tahun otak anak semakin berkembang. Neuron otaknya semakin terbuka untuk menerima informasi baru. Anak sudah mampu menyelesaikan masalah sederhana yang dihadapinya. Saat inilah kesempatan besar untuk anak belajar tentang dunianya (Schunk, 2012). Dalam penerapan practical life, anak dibebaskan memilih kegiatan yang sesuai dengan minat dan keinginannya dalam pengembangan 6 aspek perkembangan tersebut. Kegiatan aktif dan keseimbangan panca indra dalam practical life juga diarahkan pada pencegahan penggunaan teknologi komunikasi secara berlebihan, seperti penggunaan telepon genggam, gadget, game online, internet, dan akses youtube.

Perkembangan otak yang begitu pesat di usia ini, juga dipengaruhi oleh faktor lingkungan dimana anak belajar. Modeling yang dilakukan orang di sekitar anak mempengaruhi proses belajarnya. Sesuai dengan teori Bandura dalam Schunk yang menyebutkan bahwa anak lebih mudah meniru apa yang dilihatnya dari lingkungan dimana ia berada. Lebih tepatnya anak mampu mengontrol dirinya; "to control the events that affect their lives and to perceive themselves as agents" (Schunk, 2012). Proses modeling dilakukan berdasarkan pengamatan anak dari satu model ke model yang lainnya. Bahasa lainnya disebut juga dengan imitasi (imitation) yang telah dilakukan oleh peneliti bersama anak. Material yang digunakan dalam penelitian ini bersifat real, nyata dan dapat disentuh anak. Kegiatan-kegiatan seperti shalat, mengaji, makan, minum, mencuci, dan lain sebagainya, dilakukan apa adanya seperti yang dicontohkan orang tua di rumah.

\section{Perkembangan Anak Usia 3-4 Tahun}

Perkembangan subjek didik dalam penelitian ini sudah berkembang sangat baik dari berbagai aspek seperti nilai agama dan moral, fisik motorik, kognitif, bahasa, sosial emosional, dan seni kreativitas. Dari aspek agama dan moral, anak mampu melakukan gerak ibadah seperti mengangkat tangan ketika berdo'a, mengucapkan do'a-do'a pendek, mengikuti gerakan shalat orang tua, memberikan sedekah berupa uang dan barang kepada orang lain, membantu teman yang kesulitan, mengajak teman berdo'a bersama, membersihkan benda yang ada di dekatnya, menggosok gigi, menyapa, mengucapkan salam jika masuk rumah, dan bersalaman dengan orang tua ketika berpisah. Menurut hasil penelitian Syamsudin dikatakan bahwa aspek agama dan moral pada anak usia dini mencakup beberapa indikator seperti berdo'a, membersihkan diri, dan berinteraksi. (Syamsudin, 2017), (Wahab, 2018). Nilai-nilai agama tersebut diekspresikan anak dalam perilaku sehari-hari. 
Dari aspek fisik motorik kasar, anak sudah mampu berlari, menggelantung, memanjat, menaiki sepeda roda tiga, menyapu lantai, mengepel lantai, mencuci baju, mencuci piring, menjemur pakaian, membuang sampah ke tempatnya, mengangkat barang seperti dus pensil, melompat, dan menari (balet). Kategori motorik kasar adalah gerak yang menggunakan otot besar dalam beraktivitas (Ramdani \& Azizah, 2019). Pengembangan kemampuan ini dipengaruhi oleh beberapa faktor di antaranya adalah genetik, pra natal, pos natal, stimulasi, dan riwayat kelahiran prematur (Ananditha, 2017). Unsur stimulasi yang ditekankan tersebut dapat dicapai dalam latihan practical life dengan tahap yang dilalui anak.

Kemampuan anak dari aspek motorik halus yang sudah dicapai anak seperti menggambar, mewarnai, menulis huruf permulaan, memeras jeruk, mengelap meja, memotong cabe, memotong cumi, menyeka dengan skop kecil, meronce, menyusun catrige bekas, menuangkan air ke dalam plastik, menggerakkan jarinya mencari sumber internet (youtube), menjepit kertas dengan jepitan jemuran, memilah kurma, mencampur warna, mencetak warna dengan jari, membentuk dengan playdough, dan menyusun potongan kayu bekas frame menjadi bangunan. Motorik halus mencakup hal yang berkaitan dengan kemampuan dalam menggunakan jari untuk melakukan kegiatan (Pura, 2019). Kemampuan ini dapat mengarah pada latihan menulis permulaan sebelum anak memasuki sekolah dasar.

Aspek kognitif, anak mampu menyelesaikan masalah sederhana misalnya memberikan solusi jika ada masalah: "sabun untuk mencuci habis, bagaimana ya?" anak menjawab: "beli aja di warung, Mi". Memilih baju yang akan digunakan sesuai acara, misalnya memilih baju princes untuk ke pesta. Menggambarkan apa yang dilihatnya, seperti menggambar ibu A yang sedang presentasi di depan kelas dengan inisiatif sendiri kemudian mengkomunikasikan kepada ibu A tentang apa yang digambarnya. Gambaran tersebut merupakan kemampuan kognitif anak dalam berpikir yang lebih kompleks, baik untuk menalar maupun dalam hal memecahkan masalah. Menurut hasil penelitian yang dilakukan oleh Novitasari bahwa anak usia 4 tahun sebagian besar mengalami masalah dengan perkembangan kognitifnya, yaitu sebesar 39\% dan hanya 7\% anak saja yang tidak mengalami masalah dengan perkembangan kognitifnya (Novitasari, 2018). Hal ini memperlihatkan betapa perkembangan kognitif harus mendapatkan perhatian lebih dari pendidik agar anak dapat berkembang dengan optimal. Practical life mengusung latihan-latihan yang mengedepankan oleh pikir dalam menyelesaikan masalah-masalah sederhana pada anak usia 3-4 tahun.

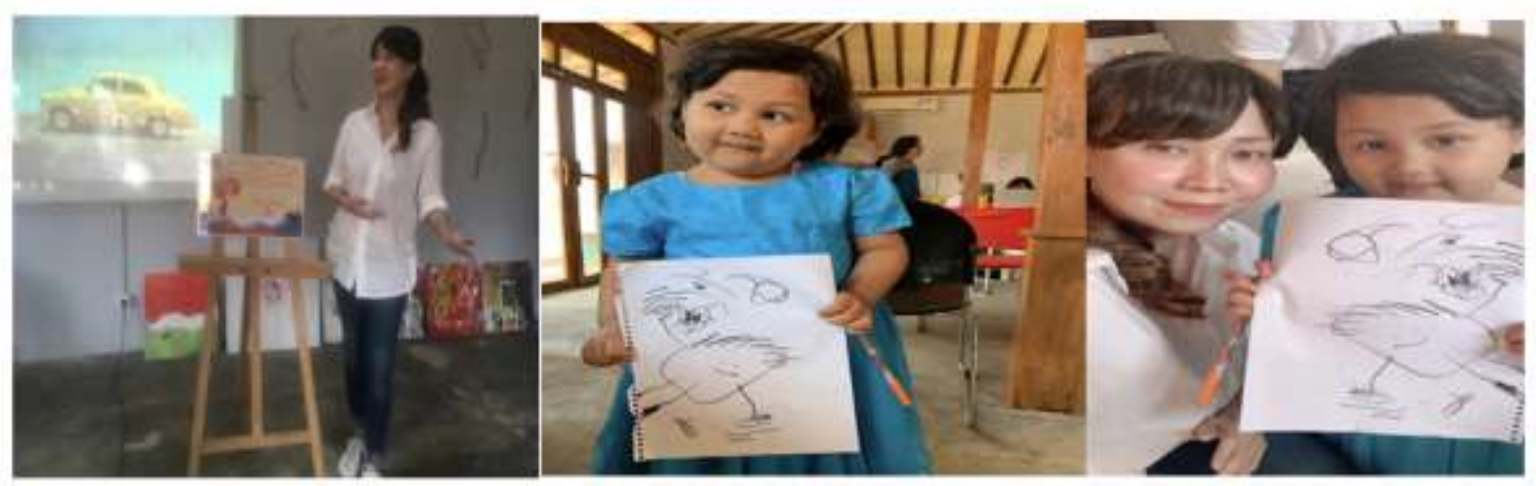

Gambar 2. Menggambar Ibu A yang sedang Presentasi

Aspek bahasa, anak sudah mampu mengutarakan keinginannya, pendapat dan ide. Mengerti perintah dan melaksanakannya bahkan dua atau tiga perintah secara sekaligus. Misalnya, "tolong Umi ya, ambil sapu lalu sapu sampah yang ada di lantai, masukkan ke dalam tong sampah". Mengkomunikasikan apa yang dilihatnya dari youtube. Secara sosial emosional, anak sudah mampu menenangkan teman yang sedang menangis, menanyakan perasaan orang lain, jika seseorang murung dia bisa bertanya: "ada apa Bang, kok Abang diam aja?". Menangis terharu ketika video dirinya ditayangkan di youtube dengan performa gala baletnya. Ketika ditanya kenapa menangis, anak menjawab; "videonya bagus". Menanyakan 
kondisi orang lain misalnya; "kapan pulang, ini sudah malam, kok belum pulang juga? Macet ya di jalan". Perkembangan bahasa dapat dilihat dari beberapa kategori seperti menyimak, berbicara, membaca, dan menulis. (Isna, 2019). Pada anak usia 3-4 tahun kemampuan menyimak dan berbicara tersebut sudah dapat dilakukan dengan baik, hanya pada kemampuan membaca dan menulis baru pada tatanan permulaan atau pengenalan.

Aspek sosial emosional, anak sudah mampu menjalin komunikasi dengan orang di sekitarnya. Menyatakan keinginannya tentang sesuatu, menjalankan perintah sederhana, mengungkapkan perasaannya, meletakkan barang di tempatnya, membuang sampah pada tempatnya. Namun pada sesekali waktu, anak menyatakan kekecewaannya dengan menangis dan sulit didiamkan dalam jedah waktu 10-20 menit. Seiring dengan kemampuan berbahasa yang semakin membaik, kemampuan berkomunikasi juga semakin berkembang. Indikator perkembangan sosial emosional menurut Dabis menyangkut kemampuan berinteraksi dengan lingkungan dan kemampuan mengendalikan emosi (Dabis, 2019). Indikator lainnya adalah kemampuan menyesuaikan diri dengan aturan yang berlaku dalam lingkungan masyarakat (Indanah \& Yulisetyaningrum, 2019).

Adapun perkembangan aspek seni dan kreativitas, anak terlihat dalam aksi yang ditampilkan di panggung balet, bermain alat musik piano, menggambar dengan menggunakan berbagai warna, mencat sepeda, kolase, meronce, mewarnai dengan spray, melukis di kanvas, finger painting, mencampur warna, dan membuat berbagai suara dari barang bekas seperti botol bekas dan karton. Seni dan kreativitas ini beriringan dengan aspek lainnya seperti fisik motorik, kognitif, dan bahasa. Menurut Sutini, seni disamping memiliki nilai estetis, juga memiliki manfaat yaitu dapat merangsang kreativitas anak dan 6 aspek perkembangan anak. Dalam seni kreativitas juga anak dapat mengekspresikan perasaan dan geraknya secara bebas (Sutini, 2018). Hal tersebut dilakukan karena ada rangsangan oleh lingkungan. Jika tidak ada rangsangan tersebut maka sulit bagi anak untuk mengembangkan kreativitasnya. Penelitian yang dilakukan oleh Kasta memperlihatkan strategi pembelajaran yang diterapkan pada TK belum mampu mengembangkan kreativitas anak karena kekurangan media yang digunakan (Kasta, 2019).

Penggunaan media memang menjadi hal yang sangat penting dalam penerapan belajar dengan practical life. Jika diterapkan pada anak, maka membutuhkan media yang bervariasi dan beragam agar anak dapat mengeksplorasi dengan baik (Sriwahyuni et al., 2017). Sebagai catatan, media yang dapat digunakan tidak harus mahal dan mewah namun dapat dimanfaatkan melalui benda atau barang-barang yang ada di sekitar anak, bahkan barang bekas juga dapat dimanfaatkan. Seperti yang sudah dilakukan oleh tim pengabdian kepada masyarakat skema Ipteks bagi Masyarakat (IbM) Kemenristekdikti tahun 2015 lalu dan sudah dimuat tutorialnya dalam https://www.youtube.com/watch? $\mathrm{v}=$ TbksC3k6xv4\&t=75s (Winata, 2019). Peragaan ini dapat juga dicontoh oleh pendidik dalam pelaksanaan pengasuhan di rumah berbasis practical life.

Kemampuan yang dicapai anak diarahkan dengan menggunakan model pengasuhan berbasis practical life yang dilakukan secara berkesinambungan dan konsisten. Dukungan orang di sekitar anak penting dikondisikan mengingat banyaknya asumsi yang menyatakan bahwa anak belum bisa melakukan tugas apa-apa atau takut anak jatuh dan alasan lainnya. Menurut Montessori seperti yang dikutip Irsad, penekanan aspek antropologis anak, penyiapan lingkungan belajar, penyediaan perlengkapan, disiplin dalam kebebasan serta penghapusan hadiah-hadiah dan hukuman menjadi faktor penting dalam proses belajar anak (Irsad, 2018).

\section{Aktivitas Pengasuhan Anak Usia 3-4 Tahun Berbasis Practical Life}

Aktivitas pengasuhan anak dimulai dari menyusun perencanaan berdasarkan need assessment yang dilihat sebelumnya. Need assessment terkait dengan tugas perkembangan yang sudah dilakukan sebelumnya yakni saat anak berusia 2-3 tahun. Hasil penelitian yang dilakukan di usia anak 2-3 tahun dapat dilihat dalam tabel berikut ini (Winata et al., 2017): 
Tabel 1. Perkembangan Anak Usia 2-3 Tahun

\begin{tabular}{|c|c|}
\hline Aspek & Perkembangan \\
\hline $\begin{array}{l}\text { Fisik } \\
\text { motorik }\end{array}$ & $\begin{array}{l}\text { Berjalan dengan baik, Mencuci tangan sendiri, Minum dari botol, Memasukkan } \\
\text { benda ke dalam gelas, Memberi minum boneka, Membubuhkan odol di atas sikat } \\
\text { gigi, Berkumur-kumur, Main kuda-kuda, } \\
\text { Menaiki sepeda roda tiga, Menumpukkan catrige bekas }\end{array}$ \\
\hline $\begin{array}{l}\text { Kognitif } \\
\text { dan bahasa }\end{array}$ & $\begin{array}{l}\text { Mengerti perintah, Menyebutkan nama anggota tubuh, Menyatakan perasaannya, } \\
\text { Menyebutkan nama panggilannya, Mengangkat tangan berdo'a }\end{array}$ \\
\hline $\begin{array}{l}\text { Sosial } \\
\text { emosional }\end{array}$ & $\begin{array}{l}\text { Datang bila dipanggil namanya, Berteman, Meminjam mainan teman, Memanggil } \\
\text { nama umi jika minta tolong, Menangis jika keinginannya tidak terpenuhi }\end{array}$ \\
\hline
\end{tabular}

Setelah melihat perkembangan terakhir anak, maka pendidik melihat Standar Nasional Pendidikan Anak Usia Dini (PAUD) yakni Standar Tingkat Pencapaian Perkembangan Anak (STPPA) yang memuat acuan untuk mengembangkan standar isi, proses, penilaian, pendidik, sarana, pengelolaan serta pembiayaan penyelenggaraan program (Anhusadar \& Islamiyah, 2020). STPPA menjadi dasar dalam pengembangan kurikulum yang terdiri dari capaian dalam bentuk tingkat pencapaian perkembangan anak pada akhir layanan. Tingkat capaian ini disebut Kompetensi Inti (KI). KI dijabarkan dalam Kompetensi Dasar (KD). Standar isi disajikan dalam bentuk tema dan sub tema yang dibuat berdasarkan kebutuhan anak, karakteristik dan tahap perkembangan anak. Pelaksanaan tema dan sub tema dilakukan dengan berbasis pada konsep practical life seperti pada gambar 3.
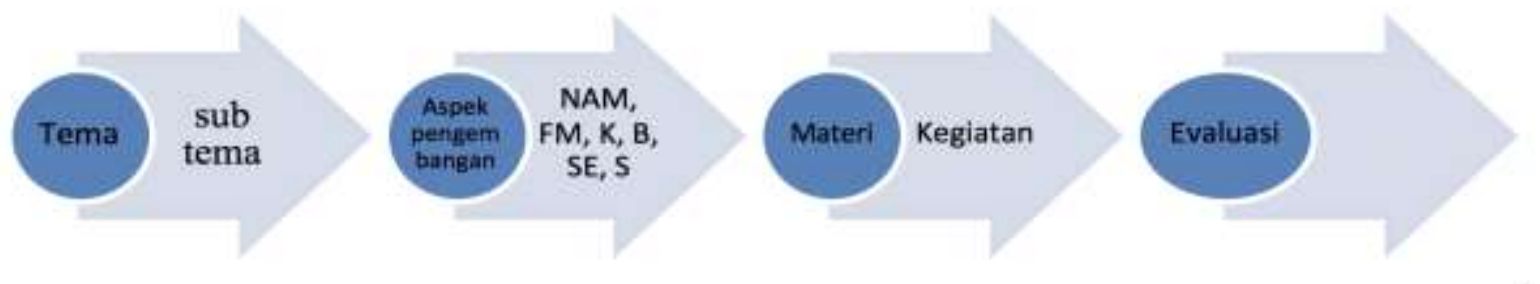

\section{Gambar 3. Tahap Pembuatan Aktivitas Belajar Practical Life}

Rangkaian tema dan sub tema dibuat dalam model webbing agar memudahkan pendidik memantau pencapaiannya. Disamping tema dan sub tema, langsung disusun rancangan aspek pengembangan yaitu Nilai Agama dan Moral (NAM), Fisik Motorik (FM), Kognitif (K), Bahasa (B), Sosial Emosional (SE) dan Seni Kreativitas. Hal ini dilakukan agar lebih mudah dalam pembuatan perencanaan pembelajaran baik secara tahunan, semesteran, mingguan maupun harian. Pemilihan bahan ajar dan media mempertimbangkan kesediaan rumah sebagai setting lingkungan. Persyaratannya harus aman, bersih dan terjaga turut menjadi pertimbangan dalam menyusun pembelajaran anak ini. Sebagi gambaran dapat dilihat pada gambar 4 .

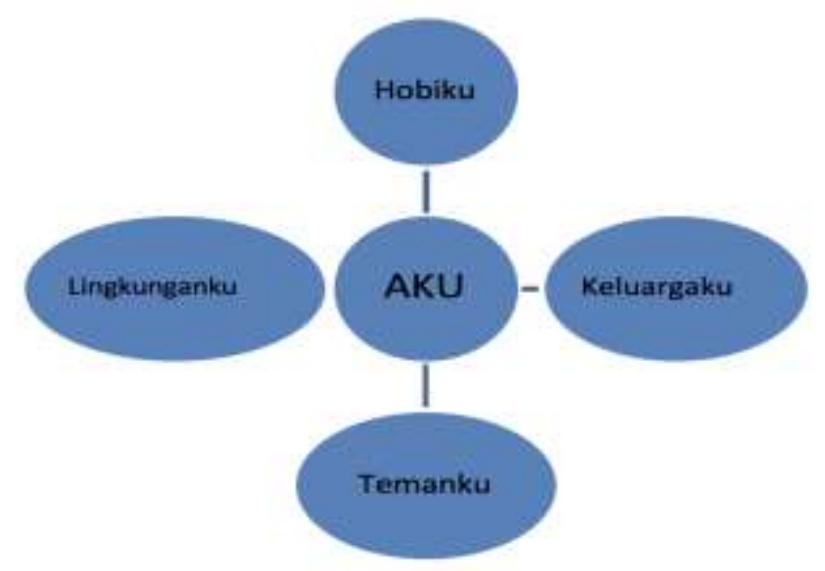

Gambar 4. Webbing Tema dan Sub Tema 
Pelaksanaan pembelajaran didasarkan pada rencana harian yang disusun dalam Aktivitas Practical Life (APL) yang terdiri dari kegiatan pembukaan, inti dan penutup. Kegiatan ini bisa saja dilakukan karena aktivitas anak tergambarkan sejak awal pembukaan pembelajaran sampai kegiatan penutup (Sugiarti, 2009). Kebebasan pendidik menentukan apa yang akan diajarkan menjadi kelebihan pola pengasuhan di rumah. Tujuan pendidikan dirancang dengan melibatkan anak dan anggota keluarga lainnya. Apa yang diharapkan orang tua dapat dituangkan dalam aktivitas practical life (Feez, 2013) seperti pada tabel 2.

Pemilihan materi, metode dan media disesuaikan dengan minat anak karena konsep practical life harus menyenangkan bagi anak. Aktivitas ini dapat dilihat dalam dokumentasi hasil penelitian di https:/ / www.youtube.com/watch?v=Ks-Jxw2zjXM (Winata, 2018). Jangan sampai anak terpaksa melakukan kegiatannya. Konsep ini sesuai dengan pendekatan belajar child centered yang mengedepankan potensi dan kebutuhan anak sesuai minatnya. Pendekatan child centered efektif diterapkan kepada anak dalam berbagai situasi pembelajaran. Bahkan dapat digunakan dalam terapi menyelesaikan persoalan psikologis anak yang mengalami hambatan termasuk persoalan kecanduan penggunaan teknologi saat ini (Glover \& Landreth, 2015). Child centered juga berkaitan erat dengan konsep konstruktivisme, aliran psikologi yang dikemukakan oleh Piaget dan Vygotsky dalam Schunk. Menurut teori ini, anak mampu mengkonstruk pengetahuannya sendiri berdasarkan pengetahuan dan pengalaman yang sudah dimiliki anak sebelumnya (Schunk, 2012). Kemampuan inilah yang dipadankan dalam konsep practical life dengan memberikan kebebasan kepada anak memilih kegiatan dan media yang diminatinya.

Proses pembelajaran yang memuat media, metode dan materi tersebut juga dibuat dengan memasukkan unsur budaya yang dimiliki anak. Misalnya ketika pendidik mendesain pembelajaran tentang tema "Cinta Tanah Air" dengan sub tema "Dirgahayu RI" dapat diajarkan kepada anak tentang pakaian adat yang digunakan dalam pawai. Kecintaan terhadap tanah air menjadi keharusan yang dipupuk sejak kecil apalagi dunia saat ini sangat terbuka dengan penggunaan teknologi yang bebas. Kekuatan cinta terhadap budaya dan tanah air harus dimasukkan dalam planning pembelajaran. Vigotsky dalam Schunk mengemukakan dalam teori sosiokultural bahwa perkembangan anak-anak dipengaruhi oleh budaya setempat dimana ia berada (Schunk, 2012). Penekanan pada interaksi sosial, kultural dan individu merupakan faktor kunci dalam perkembangan manusia. Interaksi dalam lingkungan tersebut mempercepat perkembangan kognitif seseorang. Dalam hal ini bahasa merupakan alat yang digunakan dalam berbicara dan menyampaikan pesan.

\section{Tabel 2. Aktivitas Anak}

\begin{tabular}{|c|}
\hline $\begin{array}{l}\text { Aktivitas Practical Life } \\
\text { "Mencuci pakaian" }\end{array}$ \\
\hline Tujuan aktivitas: \\
\hline 1. Membaca bismillah ketika mulai bekerja (NAM) \\
\hline 2. Membubuhkan sabun diterjen ke baju sesuai kebutuhan $(\mathrm{K}, \mathrm{S})$ \\
\hline 3. Mengenal konsep waktu, sabar menunggu 5 menit (K, SE) \\
\hline 4. Mengembangkan motorik halus dengan mengosok/mengucek pakaian, memeras (F) \\
\hline 5. Menentukan bagian yang kotor dan bagian yang bersih $(K, S)$ \\
\hline 6. Mengklasifikasikan warna pakaian; hitam, putih, abu-abu, merah $(\mathrm{K}, \mathrm{S})$ \\
\hline 7. Memilih jenis pakaian; celana, baju (K) \\
\hline 8. Membedakan panjang pendek; celana yang panjang dan celana yang pendek (K) \\
\hline 9. Bertanya tentang pakaian yang dicuci; ini baju siapa? (B, SE) \\
\hline 10. Melatih keterampilan mengangkat baju yang sudah bersih ke jemuran (F) \\
\hline 11. Mengatur tinggi rendah jemuran $(\mathrm{K}, \mathrm{F})$ \\
\hline 12. Menata baju di jemuran mulai yang rendah ke yang tinggi $(\mathrm{F}, \mathrm{K})$ \\
\hline 13. Hemat menggunakan air sesuai kebutuhan, tidak mubazir (NAM, SE) \\
\hline 14. Mengetahui proses perubahan dari kotor ke bersih $(\mathrm{K})$ \\
\hline
\end{tabular}




\section{Demonstrasi;}

Pendidik mendemonstrasikan cara mencuci pakaian dengan membubuhkan sabun bubuk ke dalam air, mengucek-ucek, merendam sekitar 5 menit. Setelah 5 menit pakaian digosokgosok pada bagian yang kotor kemudian dibilas dengan air bersih. Pakaian yang sudah bersih diperas lalu dijemur.

\section{Latihan independen;}

Anak melakukan cara mencuci pakaian dengan membubuhkan sabun bubuk ke dalam air, mengucek-ucek, merendam sekitar 5 menit. Setelah 5 menit pakaian digosok-gosok pada bagian yang kotor kemudian dibilas dengan air bersih. Pakaian yang sudah bersih diperas, diangkat lalu dijemur di jemuran. Anak bertanya pada posisi mana di jemur, yang tinggi apa yang rendah.

Materi: mencuci pakaian

Metode: demonstrasi, praktek langsung, latihan, diskusi, tanya jawab

Media: sabun diterjen bubuk, air, ember, jemuran, jepitan, hanger, slang, pakaian, sikat

\section{Relasi konteks lain;}

Anak berlatih mencuci piring, mencuci mainan dan mengelap meja dengan cairan pembersih.

\section{Evaluasi:}

\begin{tabular}{|c|c|c|c|c|}
\hline No & Indikator & 1 & 2 & 3 \\
\hline 1 & Membaca bismillah ketika mulai bekerja & & & \\
\hline 2 & Membubuhkan sabun diterjen ke baju sesuai kebutuhan & & & \\
\hline 3 & Mengenal konsep waktu, sabar menunggu 5 menit & & & \\
\hline 4 & $\begin{array}{l}\text { Mengembangkan motorik halus dengan mengosok/mengucek } \\
\text { pakaian, memeras }\end{array}$ & & & \\
\hline 5 & Menentukan bagian yang kotor dan bagian yang bersih & & & \\
\hline 6 & Mengklasifikasikan warna pakaian; hitam, putih, abu-abu, merah & & & \\
\hline 7 & Memilih jenis pakaian; celana, baju & & & \\
\hline 8 & $\begin{array}{l}\text { Membedakan Panjang pendek; celana yang Panjang dan celana yang } \\
\text { pendek }\end{array}$ & & & \\
\hline 9 & Bertanya tentang pakaian yang dicuci; ini baju siapa? & & & \\
\hline 10 & $\begin{array}{l}\text { Melatih keterampilan mengangkat baju yang sudah bersih ke } \\
\text { jemuran }\end{array}$ & & & \\
\hline 11 & Mengatur tinggi rendah jemuran & & & \\
\hline 12 & Menata baju di jemuran mulai yang rendah ke yang tinggi & & & \\
\hline 13 & Hemat menggunakan air sesuai kebutuhan, tidak mubazir & & & \\
\hline \multirow[t]{2}{*}{14} & Mengetahui proses perubahan dari kotor ke bersih & & & \\
\hline & Total nilai & 29 & & \\
\hline
\end{tabular}

\section{Keterangan:}

[1] belum tepat; belum mampu melaksanakan (1-13)

[2] sudah tepat; sudah mampu melaksanakan (13-26)

[3] sangat tepat; melebihi kemampuan standar (26-39)

\section{Deskripsi:}

Nilai anak 29 berada di posisi [3] yaitu sudah tepat. Walaupun ada beberapa yang belum mampu dilakukan dengan tepat tetapi masih bisa diupayakan dalam kegiatan relasi dengan konteks lain.

\section{Dokumentasi:}

(Foto anak sedang berkegiatan) 
Berdasarkan paparan hasil dan pembahasan penelitian di atas dapat ditegaskan bahwa model pengasuhan berbasis practical life untuk anak usia 3-4 tahun dapat digunakan dalam pola pengasuhan anak-anak Indonesia. Hal ini dinyatakan bahwa model ini sesuai dengan kondisi anak Indonesia yang berada dalam kultur budaya Indonesia, anak-anak yang berada dalam dunia digital dan era society 5.0. Perlu persiapan yang matang dari rumah oleh pendidik dengan memanfaatkan segala dukungan yang dimiliki.

Model pengasuhan berbasis practical life memiliki kelebihan dibandingkan dengan model lain yang sudah diterapkan di PAUD. Model klasikal atau bahkan sentra disusun oleh guru yang dituangkan dalam bentuk Rencana Pelaksanaan Pembelajaran harian (RPPH). Rancangan tersebut dibuat sebelum kegiatan pembelajaran dilaksanakan. RPPH berasal dari program tahunan yang disusun oleh kepala TK bersama guru (Cahyaningrum et al., 2017), (Kartini \& Waridah, 2018). Artinya, desain pembelajaran berasal dari ide guru yang dituangkan dalam aktivitas harian. Gurulah yang memulai terlebih dahulu proses pembuatan rancangan pembelajaran (teacher centered). Guru berfungsi sebagai pembuat program sekaligus pengajar. Berbeda dengan model pengasuhan berbasis practical life, anak yang memunculkan terlebih dahulu kegiatan (student centered), barulah guru membuat rancangan yang bernuansa korelasi konteks lain. Korelasi ini mengarahkan guru untuk menelusuri kegiatan serupa namun memiliki tingkat ketercapaian kemampuan yang lebih tinggi dari kegiatan sebelumnya. Sesuai dengan teori Vygotsky bahwa anak belajar dengan konsep scaffolding, perancangan yang dilakukan secara bertahap dan berkesinambungan, mulai dari aktivitas yang mudah kemudian berangsur menuju aktivitas yang lebih sulit. Jika anak mampu melakukan tugasnya maka pendidik memberikan kesempatan dan kebebasan dalam berkegiatan, namun jika anak mengalami kesulitan maka pendidik bisa membantu sesuai dengan porsinya (Schunk, 2012).

\section{SIMPULAN}

Practical life dapat diterapkan pada pengasuhan anak usia 3-4 tahun dengan menekankan aspek minat dan keseimbangan 6 aspek pengembangan sebagai antisipasi pengaruh negatif penggunaan teknologi saat ini. Model pengasuhan berbasis practical life juga dapat dijadikan sebagai layanan pendidikan alternatif (homeschooling) disamping pendidikan formal lainnya. Model ini berfungsi sebagai suplemen bahan pembelajaran bagi pendidik di rumah tangga agar dapat menyusun proses pembelajaran untuk anak di rumah. Langkah yang dilakukan pendidik dapat diawali dengan mengenali anak terlebih dahulu melalui need assessment, kemudian menyusun kegiatan yang sesuai. Proses penilaian juga dilakukan agar pendidik dapat melihat ketercapaian belajar anak dari hari ke hari.

\section{UCAPAN TERIMA KASIH}

Terima kasih kepada Kemenristekdikti yang sudah mendanai penelitian ini dengan skema Penelitian Terapan Unggulan Perguruan Tinggi (PTUPT) 2019 berdasarkan Surat Keputusan Nomor 7/E/KPT/2019 dan Nomor: 109/SP2H/LT/DRPM/2019. Perjanjian kontrak Nomor: 296/R-UMJ/IV/2019 (Daftar Nomor Surat Keputusan UMJ, 2019). Tulisan ini adalah salah satu luaran tambahan yang dipublikasikan di samping luaran-luaran lainnya. Terima kasih kepada Fakultas Ilmu Pendidikan, Lembaga Penelitian dan Pengabdian Masyarakat, Universitas Muhammadiyah Jakarta yang telah memberikan kesempatan untuk meneliti. Terima kasih untuk tim redaksi, editor, dan reviewer Jurnal Obsesi yang sudah memberikan arahan kepada penulis hingga terbitnya tulisan ini.

\section{DAFTAR PUSTAKA}

Ananditha, A. C. (2017). Faktor-Faktor Yang Berhubungan Dengan Perkembangan Motorik Kasar Pada Anak Toddler. Jurnal Keperawatan Muhammadiyah, 2(1). https://doi.org/10.30651/jkm.v2i1.924 
Anhusadar, L. O., \& Islamiyah, I. (2020). Kualifikasi Pendidik PAUD Sesuai Permendikbud Nomor 137 Tahun 2014. Journal on Early Childhood Education Research (JOECHER), 1(2), 55-61. https://doi.org/10.37985/joecher.v1i2.8

Bhatia, P., Davis, A., \& Shamas-Brandt, E. (2015). Educational gymnastics: The effectiveness of montessori practical life activities in developing fine motor skills in kindergartners. Early Education and Development, 26(4), 594-607. https://doi.org/10.1080/10409289.2015.995454

Cahyaningrum, E. S., Sudaryanti, S., \& Purwanto, N. A. (2017). Pengembangan Nilai-Nilai Karakter Anak Usia Dini Melalui Pembiasaan Dan Keteladanan. Jurnal Pendidikan Anak, 6(2), 203-213. https://doi.org/10.21831/jpa.v6i2.17707

Creswel, J. W. (2009). Qualitative, quantitative, and mixed methods approaches. Research Design Qualitative Quantitative and Mixed Methods Approaches. In Research Design.

Dabis, Y. (2019). Asesmen Perkembangan Sosial Emosional Anak Usia Dini. Jambura Early Childhood Education Journal, 1(2), 55-65. https://doi.org/10.37411/jecej.v1i2.59

Efendi. (2018). Revolusi Pembelajaran Berbasis Digital (Penggunaan Animasi Digital Pada Start Up Sebagai Metode Pembelajaran Siswa Belajar Aktif). Habitus: Jurnal Pendidikan, Sosiologi, Dan Antropologi. https:// doi.org/10.20961/habitus.v2i2.28788

Feez, S. (2013). Montessori and Early Childhood: A Guide for Students. In Montessori and Early Childhood: A Guide for Students. SAGE Publications Ltd. 1st edition (October 16, 2009). https://doi.org/10.4135/9781446269343

Fitri, I. (2018). Peningkatan Kemandirian Anak Melalui Pembelajaran Practical Life di TK Annisa. Raudhatul Athfal: Jurnal Pendidikan Islam Anak Usia Dini, 2(1), 23-45. https://doi.org/10.19109/ra.v2i1.2234

Glover, G., \& Landreth, G. L. (2015). Child-Centered Play Therapy. In Handbook of Play Therapy: Second Edition (pp. 93-118). https:// doi.org/10.1002/9781119140467.ch5

Indanah, I., \& Yulisetyaningrum, Y. (2019). Perkembangan Sosial Emosional Anak Usia Pra Sekolah. Jurnal Ilmu Keperawatan Dan Kebidanan, 10(1), 221. https://doi.org/10.26751/jikk.v10i1.645

Irsad, M. (2018). Metode Maria Montessori Dalam Perspektif Filsafat Pendidikan. Jurnal Komunikasi Pendidikan, 1(1), 51. https:// doi.org/10.32585/jkp.v1i1.16

Isna, A. (2019). Perkembangan Bahasa Anak Usia Dini. Wardah, I(1), 62-69. https://doi.org/10.29240/zuriah.v1i2.2100

Kartini, K., \& Waridah, W. (2018). Implementasi pembelajaran tematik pada pendidikan anak usia dini. JPPM (Jurnal Pendidikan Dan Pemberdayaan Masyarakat), 5(2), 191-201. https:// doi.org/10.21831/jppm.v5i2.23132

Kasta, A. (2019). Peningkatan kreativitas seni anak melalui kolase dengan menggunakan daun pisang di TK Aisyiyah Talaok. JRTI (Jurnal Riset Tindakan Indonesia), 4(1), 19. https:// doi.org/10.29210/3003297000

Kurniawati, N., \& Hayati, T. (2020). Meningkatkan Kemandirian Anak Melalui Kegiatan Practical Life Skill. (JAPRA) Jurnal Pendidikan Raudhatul Athfal (JAPRA), 3(1), 49-60. https://doi.org/10.15575/japra.v3i1.8105

Lillard, A. S. (2013). Playful learning and Montessori education. American Journal of Play.

Lumanta, E., Gunawan, P. R., \& Tjandra, M. (2019). Perancangan Media Informasi Untuk Menanggulangi Kecanduan Gawai Pada Anak. Serat Rupa, 3(1), 48-60. https://doi.org/10.28932/srjd.v3i1.1055

Marshall, C. (2017). Montessori education: a review of the evidence base. Npj Science of Learning, 2(1), 1-9. https:// doi.org/10.1038/s41539-017-0012-7

Munisa. (2020). Pengaruh Penggunaan Gadget Terhadap Interaksi Sosial Anak Usia Dini Di TK Panca Budi Medan. Jurnal Abdi Ilmu, 13(1), 102-114.

Novitasari, Y. (2018). Analisis Permasalahan "Perkembangan Kognitif Anak Usia Dini". PAUD Lectura: Jurnal Pendidikan Anak Usia Dini, 2(01), 82-90. https://doi.org/10.31849/paudlectura.v2i01.2007

Nuraina, Damayanti, E., \& Ikawati, A. (2018). Digital Media Dongeng Berbasis Animasi Sebagai. Jurnal Likhitaprajna, 20(2), 177-183. 
Nurendah, G., Musthofa, M. A., \& Maslihah, S. (2019). Model Pengasuhan Bagi Anak Didik LPKA. Jurnal Psikologi Insight, 3(2), 80-87. https:// doi.org/10.17509/insight.v3i2.22348

Nurhidayati, N., Sugiyah, S., \& Yuliantari, K. (2021). Pengaturan Perlindungan Data Pribadi Dalam Penggunaan Aplikasi Pedulilindungi. Widya Cipta: Jurnal Sekretari Dan Manajemen, 5(1), 39-45. https:// doi.org/10.31294/widyacipta.v5i1.9447

Pura, D. N. (2019). Perkembangan Motorik Halus Anak Usia Dini Melalui Kolase Media Serutan Pensil. Jurnal Ilmiah Potensia, 4(2), 131-140. https://doi.org/10.33369/jip.4.2.131-140

Ramdani, L. A., \& Azizah, N. (2019). Permainan Outbound untuk Perkembangan Motorik Kasar Anak Usia Dini. Jurnal Obsesi: Jurnal Pendidikan Anak Usia Dini, 4(1), 494. https://doi.org/10.31004/obsesi.v4i1.407

Rantina, M. (2015). Peningkatan Kemandirian Melalui Kegiatan Pembelajaran Practical Life (Penelitian Tindakan di TK B Negeri Pembina Kabupaten Lima Puluh Kota, Tahun 2015). Jurnal Pendidikan Usia Dini, 9, 181-200. https://doi.org/10.21009/JPUD.091

Risma, D., Solfiah, Y., \& Satria, D. (2019). Pengembangan Media Edukasi Perlindungan Anak Untuk Mengurangi Kekerasan Pada Anak. Jurnal Obsesi : Jurnal Pendidikan Anak Usia Dini, 4(1), 460. https://doi.org/10.31004/obsesi.v4i1.322

Rule, A. C., \& Stewart, R. A. (2002). Effects of practical life materials on kindergartners' fine motor skills. Early Childhood Education Journal. https://doi.org/10.1023/A:1016533729704

Santoso, A. (2017). Pengaruh Konten Post Instagram terhadap Online Engagement: Studi Kasus pada Lima Merek Pakaian Wanita. Jurnal Sains Dan Seni ITS, 6(1), 50-54. https://doi.org/10.7454/jvi.v6i2.119

Schunk, D. H. (2012). Learning theories: An educational perspective. In Reading.

Sriwahyuni, E., Asvio, N., \& Nofialdi, N. (2017). Metode Pembelajaran Yang Digunakan PAUD (Pendidikan Anak Usia Dini) Permata Bunda. ThufuLA: Jurnal Inovasi Pendidikan Guru Raudhatul Athfal, 4(1), 44. https://doi.org/10.21043/thufula.v4i1.2010

Stendler, C. (1965). The Montessori Method. Educational Forum, 29(4), 431-435. https://doi.org/10.1080/00131726509339429

Sugiarti, D. Y. (2009). Mengenal Home Schooling Sebagai Lembaga Pendidikan Alternatif. Edukasi, 1(2), 13-22. http://jurnal.unismabekasi.ac.id/index.php/edukasi/article/view/691

Sutini, A. (2018). Pembelajaran Tari Bagi Anak Usia Dini. Cakrawala Dini: Jurnal Pendidikan Anak Usia Dini, 3(2). https://doi.org/10.17509/cd.v3i2.10333

Syamsudin, A. (2017). Evaluasi Ketercapaian Standar Isi Perkembangan Nilai-Nilai Agama Dan Moral Anak Usia Dini Pada Semester Gassal 2016/2017 Kb/Tk Pedagogia. Jurnal Pendidikan Anak, 5(2). https:// doi.org/10.21831/jpa.v5i2.12374

Tampubolon, G. N., Nurani, Y., \& Meilani, S. M. (2019). Pengembangan Buku Pendidikan Seksual Anak Usia 1-3 Tahun. Jurnal Obsesi : Jurnal Pendidikan Anak Usia Dini, 3(2), 527. https://doi.org/10.31004/obsesi.v3i2.243

Utami, P., \& Mubarak, A. (2018). Model Pengasuhan Anak Terkait Penggunaan Internet di Asia. Prosiding Nasional Psikologi. http:// proceeding.unisba.ac.id/index.php/PronaP/article/view/1493

Wahab, W. (2018). Implementasi Pendidikan Agama Islam Pada Pendidikan Anak Usia Dini (PAUD). PUSAKA, 6(1), 79-92. https:// doi.org/10.31969/pusaka.v6i1.39

Winata, W. (2018). Penerapan Model Homeschooling untuk Anak Usia Dini Berbasis Practical Life. Dikti.

Winata, W. (2019). Alat Peraga Edukatif dari Barang Bekas. https://www.youtube.com/watch?v=TbksC3k6xv4

Winata, W., Khaerunnisa, K., \& Farihen, F. (2017). Perkembangan Seksual Anak Usia Dua Tahun (Studi Kualitatif Perkembangan Seksual Pada Zakia). JPUD - Jurnal Pendidikan Usia Dini, 11(2), 342-357. https:// doi.org/10.21009/JPUD.112.12

Wulandari, H., \& Purwanta, E. (2020). Pencapaian Perkembangan Anak Usia Dini di Taman Kanak-kanak selama Pembelajaran Daring di Masa Pandemi Covid-19. Jurnal Obsesi : Jurnal Pendidikan Anak Usia Dini, 5(1), 452. https://doi.org/10.31004/obsesi.v5i1.626 